\title{
SUPPORT FOR THE AGRICULTURAL INVESTMENT IN POLAND - DOMESTIC VERSUS CAP
}

\author{
Alina Danilowska ${ }^{1}$, associate professor \\ ${ }^{1}$ Warsaw University of Life Sciences-SGGW, Department of Economics and Economic Policy, Poland
}

\begin{abstract}
Although Poland's accession to the European Union (EU) in 2004 has offered the great opportunities for the modernization of the Polish agriculture in the form of access to vast range of support under Common Agricultural Policy, the state aid existing before accession was not abandoned. The aim of the paper is to assess the scope and size of the domestic support for the investment in agriculture in the context of the support for such activity under the EU Rural Development Programs (RDPs) in years 2004-2017. The examination revealed that in the period of Poland's membership in the EU, the state credit aid system has conducted operations on slightly changed rules, however, in 2015 the scope of the credit support was reduced noticeably. The comparison of the number of beneficiaries and value of the state credit aid and aid under RDPs during three financial perspectives indicates the very important relative role of preferential credits in financing the modernisation of the Polish agriculture. Nearly one quarter of market oriented agricultural holdings used preferential credits in years 20042017, while the small and semi subsistence farms were important group of beneficiaries of RDP. Although the difference between the nature of the state and EU aids (repayable credits and subsidised expenditures) they complemented each other. The decrease in the preferential credit lines and following fall in the number of credits, suggest that the role of the preferential credits in modernisation and restructuring of the agriculture will fall unavoidably.
\end{abstract}

Key words: subsidised credits, agricultural holdings, Common Agricultural Policy, state aid. JEL code: $\mathrm{Q}_{14} \mathrm{Q}_{18}$

\section{Introduction}

Poland's accession to the European Union (EU) in 2004 has offered great opportunities for the modernization of the Polish agriculture as agriculture has gained access to the vast range of support under Common Agricultural Policy (CAP). However, the existing before accession forms of backing the modernisation were not abandoned. In result, since 2004, the agriculture has had possibility to benefit from two sources of the help - domestic and the EU's.

The justification of the public support for the agriculture is a well-recognised issue. Examination of the intervention basis from historical perspective indicates that the list of reasons for support for agriculture as a sector of economy or its particular areas have been extending gradually. What more, the regional differences in that area are noticed? For example, Moor (1987) indicates that the intervention in agriculture in United States in Great Depression 1929-19332 was based on the idea of equity of a fair distribution of wealth. Many Authors consider interventions as a response to the characteristics and impacts of the so called "farm problem" that is complex phenomenon including such features of agricultural activity like for example price and income inelastic demand, small producer operations, climate conditions and other uncontrollable factors, buyers concentration and many others (Jelic M.A. et al, 2014, Brodeur C., Clerson F. (2015). Now days public support for agriculture is often seen as a solution of the problems generated by market failures like externalities, public goods and transaction costs (Marsh J., 1992, Romstad E. 2002, Jongeneel R.A., Ge L., 2010, Hagedorn K., 2008, Vanni F., 2014). Danilowska A., 2015). Many authors use the approach of the New Political Economy and see the support system as a result of the interactions between economic and political agents and rent seeking behaviour (Paapi F.U., Henning C., 1999, Nedergaard F.U., 2006, Zawojska A., 2011, Hvid, A., 2014, Poczta-Wajda A., 2016). As Katto-Andrighetto J. et al.

\footnotetext{
1 Tel.: +48 22 5934039; fax: +48 22 5934031, E-mail address:alina_danilowska@sggw.pl

2 The year of the start of a major intervention by the federal government into agriculture
} 
(2017) noticed „public support reflects a political choice that is influenced by many factors such as the overall political and economic situation of a country, the balance of political forces at a given moment, broader societal choices and perceptions regarding food production, or the relative power of influence of civil society movements and professional lobbies".

The aim of the research is to assess the scope and size of the domestic aid for the investment in agriculture in the context of the support for such activity under EU Rural Development Programs in years 2004-2017.

In the paper, the hypothesis "The domestic support for investment in agriculture has continue to be important for agriculture modernisation and restructuring after Poland's accession to EU” is verified.

The research concerns some problems (i) the evolution of the domestic support in Poland after Poland's accession to EU, (ii) the scope and value of the domestic aid for agriculture versus EU one.

\section{Materials and methods}

The Agency for Restructuring and Modernisation of the Agriculture (ARMA) is the main source of information and data. It is responsible for implementation of instruments offered under Common Agricultural Policy (CAP) as well as providing the support from national funds.

To achieve the paper's aim the comparative method was applied.

In the paper expressions „agricultural holding” and „farm” are used interchangeably.

\section{Research results and discussion}

\section{The government aid for agriculture before 2004 in Poland}

With the accession to the EU, the Polish agriculture has gained access to different measures offered under CAP. They have enlarged the range of support forms the Polish farmers were offered before 2004. It is worth to underline that the domestic aid had long tradition in Poland. It existed during the communistic period as well, and next, it was used during transition to market economy quite early as in April of 1990. It took form of subsidised bank credits granted to farmers for financing the purchase of current means of production and some kinds of investment.

In 1994, the system of the government aid for modernisation and restructuring of the agriculture was brought into operation. For management of the system the state agency - Agency of Restructuring and Modernisation of Agriculture was established. The credits, so called preferential credits, with subsidy to interest rate were the main form of the support. The credits were granted by banks that signed agreement with ARMA from their own funds and on their own risk. Although the credits for current means of production were continued', the strong emphasis on support for the investment was given. Credits were allowed within lines of credits limits. There were three the most popular ones: basic investment credit line, line for young farmers and line for land purchase. The credit lines varied by targets, eligible agents and the level of subsidies. The scope of the credits was nearly all-encompassing. They were available for very vast range of investment in agriculture and for investment in some food industries. It stemmed from the agricultural policy that was trying to help to overcome the relative technological disadvantage of the Polish agriculture and unfavourable farm structure ${ }^{2}$. Beside regular subsidised credits for investment, the system encompassed the investment and current credits for overcoming effects of natural disasters. The credits were available to agricultural holdings (individual farmers, agricultural enterprises) and to enterprises operating in

\footnotetext{
1 The ARMA was responsible for organisational issues connected to granting the working credits on behalf Ministry of Agriculture.

${ }^{2}$ In 1990 the number of private farms was amounted to 2138 thousand, the average area of agricultural land per farm was 6.3 ha. $52.8 \%$ of the farms owned less than 5 ha of land and only $6.1 \%$ more than 15 ha (Central Statistical Office, 1991).
} 
food industries. The terms of subsidised credits were very advantageous comparing to market terms of commercial credits especially in the 90ties (Danilowska A., 2004). To restrain banks from charging very high interest rate the cup on the interest rate was introduced linked to central bank discount rate by multiplier. In the beginning, it was set up at 1.5, but it was changed several times. Borrowers paid only 0.5 bank interest rate in the case of basic investment credits, and 0.25 central bank discount rate in the case of credits for purchase of agricultural land or granted for farmers less than 40 years old.

The number of the granted subsidised investment credits varied year to year (Fig. 1). In the beginning it rose quickly from nearly 16000 in the first year to 58325 two years later, in 1997 it fell slightly to 56570 and next in 1998 it dived to 17314 because of the reduction of the credit line number and the funds for new credits. During the following five years it fluctuated noticeably and in 2003 got 24263.

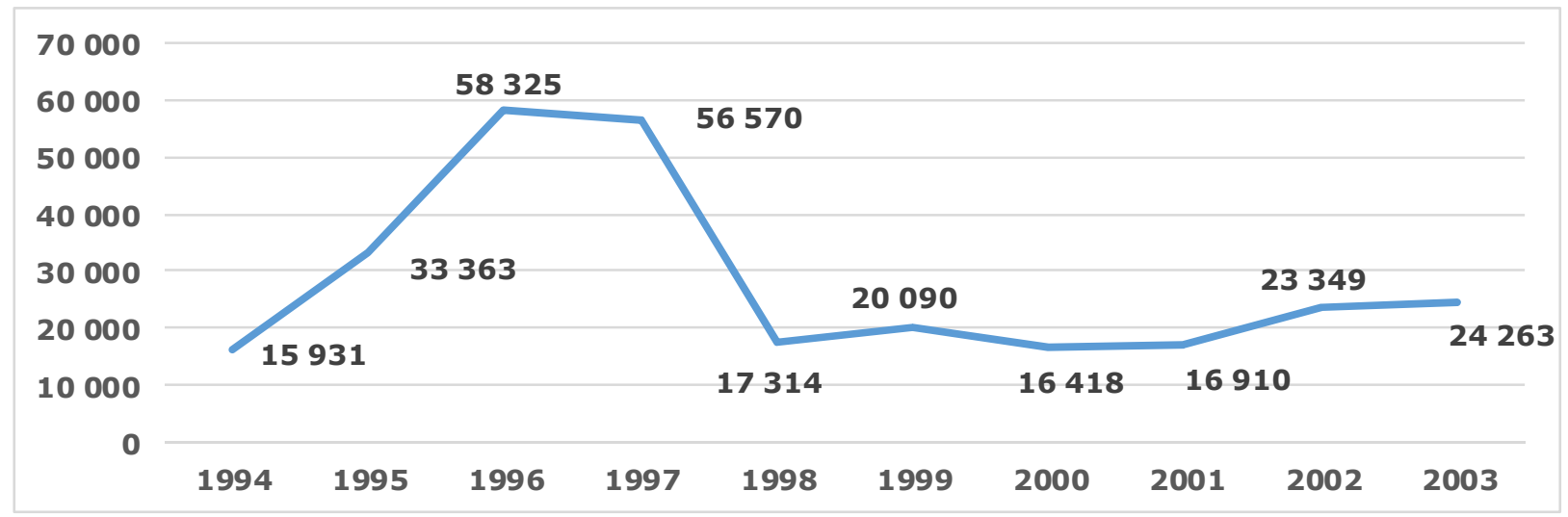

Source: author's calculations based on Annual Reports of ARMA

Fig. 1. Number of preferential investment credits granted to farmers in 1994-2003

In total, during 1994-2003 283533 preferential investment credits were granted to farmers. Taking into consideration that in 2002 the total number of farms conducting activity in Poland was amounted at 2172205 (Eurostat, 2002) and the examined period is 10 years long, the number of credits is not stunning. But assuming that only about 750000 market oriented farmers (FADN, 2004) were interested in such credits the evaluation of their role changes for much more positive. It is worth to mention that during the years 1994-2003 hundreds of thousands subsidised agricultural working credits were granted every year in parallel.

\section{The government aid for agriculture after accession to the EU}

For the first three years after accession to the EU, the preferential investment credit system continued to operate on the unchanged terms on the basis so-called "existing aid". The scope of the investment credits was even boarded as two new credit lines were introduced.

Since May of 2007, the system was adjusted to the Community guidelines for State aid in the agricultural and forest sectors 2007 to 2013 (European Commission, 2006). Although the reduction of the number of credit lines from thirteen to nine took place, the scope of credits remained nearly the same as the most popular credit lines sustained operations. What more, gradually in the following years new credit lines were set up again, however, they did not draw much attention of potential borrowers. The terms of credits changed slightly. A new regulation introduced the ratio of intensity of support ${ }^{1}$. The limit of maximum value of subsidies was set up at a $40-75 \%$ of credit value. The

\footnotetext{
${ }^{1}$ The maximum level of subsidies per agent.
} 
level depended on the kind of investment credit line. In 2010, a new credit tool was introduced. It was the credit with the repayment of the part of credit capital by state.

In 2015, Agency implemented new rules for the operating of subsidised credit system that were adjusted to New perspective of domestic support for 2015-2020 and new regulations of EU on de minims support in agriculture (European Commission 2013; European Commission 2014). The number of credit lines was decreased to five. Four of them was connected to agriculture, one to food processing. The interest rate cup was tied to WIBIOR ${ }^{1}$ and its maximal level was set up at WIBOR + 2.5 percentage points but not less than $3 \%$. The interest rates for the borrowers were unified at 0.67WIBOR regardless the credit line 2 . In 2017 the credits were granted under six credit lines. Two of them were designed for typical agricultural investment, one for food processing, two for overcoming the effects of natural disasters and one for repayment liabilities of agricultural enterprises -producers of milk, fruits since August $7^{\text {th }}$ to April 30 2016.

\section{Credit state aid for investment in agriculture and CAP support}

Agriculture of the EU members gets support within of Common Agricultural Policy. Since accession, the Polish farmers has been enabled to participate in measures offered during three financial perspectives: 2004-2006³, 2007-2013 and 2014-2020. Subsidies to the expenditures for indicated activities are the main form of the support.

In financial perspective 2004-2006 agriculture in Poland were offered aid within Rural Development Programme for 2004-2006 (RDP 2004-2006) and Sectoral Operational Programme (SOP). Under RDP 2004-2006, the Polish agricultural holdings were eligible to two groups of measures: (i) the same measures like in "old" EU members (15): support for agricultural holdings in less favoured areas (LFA), structural pensions, support for agricultural-environmental activities and improving animal health and welfare, afforestation of agricultural land, (ii) measures designed for new EU members: support to semi-subsistence farms, support to group of producers, support for adjustment of agricultural holdings to the EU standards, technical support. These measures concerned different important issues but generally supported very limited scope of investment in agriculture. Only the support to semi-subsistence farms and for adjustment of agricultural holdings to the EU standards could be treated as an aid for investment.

Contrary to RDP 2004-2006, the Sectoral Operational Program (SOP) - "Restructuring and Modernization of the Food Sector and Rural Development" had pro-investment character. Program offered measures like: investment in agricultural holdings, setting up of young farmers, improving processing and marketing of agricultural products, diversification of agricultural activities and activities close to agriculture to provide multiple activities or alternative incomes, development and improvement of the infrastructure related to agriculture. Two first measures were strictly devoted for modernisation and restructuring the agricultural holdings whereas others supported this process indirectly.

In 2004-2006, alongside the support from aforementioned measures farmers could applied for subsidised investment credits from lines: Basic investment credits (IP), Credits to young farmers $(M R)$, Credits for purchase of agricultural land (KZ), Credits for launching or enlargement of family farm (GR), Credits for farm establishing or equipment within the Ministry of Agriculture program of

\footnotetext{
WIBOR - Warsaw Interbank Offered Rate.

2 Except the credits for overcoming the effects of serious natural disasters. In this case the interest rate is established at $1.5 \%$.

3 Poland joined the EU during the financial perspective 2000-2006.
} 
settlement on state land (OR), Credits for new technologies (NT) (Table 2), and some credit lines for food processing. The first three were quite popular, the importance of the others was marginal.

Table 1

\section{Number and value of investment subsidised investment credits versus number and value of subsidised investment projects in agriculture under RDP 2007-2013 (December 2014)}

\begin{tabular}{|l|c|c|}
\hline \multicolumn{1}{|c|}{ Specification } & Number & $\begin{array}{c}\text { Value } \\
\text { (OOO'OOO PLN) }\end{array}$ \\
\hline Preferential credits & 63952 & 6286 \\
\hline $\begin{array}{l}\text { RDP 2004-2006: } \\
\text { - support to semi-subsistence farms } \\
\text { - support for adjustment of agricultural holdings to the EU } \\
\quad \text { standards }\end{array}$ & 157600 & 1316 \\
$\begin{array}{l}\text { SOP: } \\
\text { - investment in agricultural holdings } \\
\text { - setting up of young farmers } \\
\text { - TOTAL }\end{array}$ & 71300 & 2430 \\
\hline & & \\
\hline
\end{tabular}

1 in the case of preferential credits the value of granted credits in nominal terms

Source: Annual Reports on Activity of the ARMA (2004-2007). ARMA. Warsaw 2005-2008.

As data in the Table 1 indicate, the agricultural holdings were very interested in the support under SOP and RDP 2004-2006, especially in the support for semi-subsistence farms. It stemmed from the very advantageous terms of that measure. Such farms were generally less interested in preferential credits with the necessity of the repayment of capital. Although the number of preferential credits was four times lower, the value of the credits were only $10 \%$ lower. So the credits were the valuable source of the investment financing equal CAP investment measures.

Table 2

\section{Credit lines supporting agricultural land purchase available in consecutive} subs financial perspectives

\begin{tabular}{|c|c|c|c|c|c|c|c|c|c|c|c|c|c|c|}
\hline \multirow{3}{*}{$\begin{array}{c}\text { Cred } \\
\text { it } \\
\text { line }\end{array}$} & \multicolumn{3}{|c|}{ 2004-2006 } & \multicolumn{7}{|c|}{ 2007-2013 } & \multicolumn{4}{|c|}{ 2014-2020 } \\
\hline & 200 & 200 & 200 & 200 & 200 & 200 & 201 & 201 & 201 & 201 & 201 & 201 & 201 & 201 \\
\hline & 4 & 5 & 6 & 7 & 8 & 9 & $\mathbf{0}$ & 1 & 2 & 3 & 4 & 5 & 6 & 7 \\
\hline IP & $x$ & $x$ & $x$ & $x$ & $x$ & $x$ & $x$ & $x$ & $x$ & $x$ & $x$ & $x$ & $x$ & $x$ \\
\hline $\mathbf{K Z}$ & $x$ & $x$ & $x$ & $x$ & $x$ & $x$ & $x$ & $x$ & $x$ & $x$ & $x$ & $x$ & $x$ & $x$ \\
\hline MR & $x$ & $x$ & $x$ & $x$ & $x$ & $x$ & $x$ & $x$ & $x$ & $x$ & $x$ & & & \\
\hline GR & $x$ & $x$ & $x$ & $x$ & $x$ & $x$ & $x$ & $x$ & $x$ & $x$ & $x$ & & & \\
\hline OR & $x$ & $x$ & $x$ & $x$ & $x$ & $x$ & $x$ & & & & & & & \\
\hline $\mathbf{N T}$ & $x$ & $x$ & $x$ & $x$ & $x$ & $x$ & $x$ & $x$ & $x$ & $x$ & $x$ & & & \\
\hline CSK $^{2}$ & & & & & & & $x$ & $x$ & $x$ & $x$ & $x$ & $x$ & & \\
\hline
\end{tabular}

${ }_{1} I P$ - Basic investment credits, since 2015 acronym RR; KZ - Credits for land purchasing, since 2015 acronym Z; MR - Credits to young farmers, GR - Credits for launching or enlargement of family farm, OR - Credits for farm establishing or equipment in the frame of Ministry of Agriculture program of settlement on state land, NI - credits for new technologies, CSK - Credits with the repayment of part of capital, since 2015 acronym MRcsk

2 since 2015 available only to young farmers for land purchase

Source: author's research based on Annual Reports of ARMA

In next financial perspective 2007-2013, the system of CAP was reformed and the support for the agriculture was arranged under the Rural Development Programme for 2007-2013 (RDP 2007-2013). It offered 21 measures under four axes but as in the financial perspective 2004-2006, the direct support for the investment in agriculture was offered only by some measures like: "Setting up young farmers", "Modernization of farms" and „Farmers' participation in the quality food systems". They 
were quite similar to measures from the former financial perspective. The scope of the aims of investment that could be subsidised under these measures was rather vast.

In 2007-2013, agricultural holdings were offered the same credit lines like before (Table 2). Moreover, in 2010 as aforementioned credit with subsidy to the repayment of the capital was introduced.

Table 3

\section{Number and value of investment subsidised investment credits versus number and value of subsidised investment projects in agriculture under RDP 2007-2013 (December 2014)}

\begin{tabular}{|l|c|c|}
\hline \multicolumn{1}{|c|}{ Specification } & Number & Value $^{\mathbf{1}}$ (thousand PLN) \\
\hline Preferential credits & 98578 & 18518.4 \\
\hline RDP 2007-2013 & & \\
\hline $\begin{array}{l}\text { - setting up young farmers, } \\
\text { - modernization of farms, } \\
\text { - participating farmers in the quality food systems } \\
\text { TOTAL }\end{array}$ & 31024 & 2381.5 \\
\cline { 2 - 3 } & 66077 & 9464.7 \\
\cline { 2 - 3 } & 26527 & 11898.1 \\
\hline
\end{tabular}

1 in the case of preferential credits, the value of granted credits in nominal terms

Source: Annual Reports on Activity of the ARMA (2007-2014). ARMA. Warsaw 2008-2015.

The comparison of the number and values of subsidised credits with the number and value of projects under RDP 2007-2013 highlights the very important role of the credits in examined years. Although their number was lower than number of projects supported under RDP 2007-2013, the value was about $55 \%$ higher. It was a result of the very broad scope of the credits that could finance nearly every kind of investment. It is worth to mentioned that such important investment like the purchase of agricultural land could be financed only by credits.

In current financial perspective 2014-2020, the Polish RDP 2014-2020 14 measures are envisaged for six priorities. The measure M04 - Investments in physical assets directed for modernization and farm restructuring has the highest proportion in the total indicative planed expenditure (the EAFRD support and the national contribution) amounted at 25 \% (The European..., 2015). Under this measure the operations "modernization of farms", "investment in farms located on Areas of Natural Constrains”, "investment in farms located on Areas of Natura 2000" are of strict investment character, whereas in measure M05- Damage/restoration/prevention actions operation "restoration of agricultural production capability”. Moreover, under measure M06 „Farm \& business development” the sub measures "start-up aid for young farmers" and "restructuring of small farms" can be treated as support for investment in agriculture.

In the first year of the financial perspective 2014-2020, the system of preferential credit offered the same credit lines as in former perspectives. As aforementioned, in 2015 the new regulation was introduced and the number of preferential investment credit lines were abandoned. Agricultural holdings can obtain the investment subsidised credit only under lines: basic investment and land purchase. 


\begin{abstract}
Number and value of investment subsidised investment credits versus number and value of subsidised investment projects in agriculture under RDP 2014-2020 in years 2014-2017 (December 2017)
\end{abstract}

\begin{tabular}{|c|c|c|}
\hline Specification & Number & $\begin{array}{c}\text { Value }^{1} \\
\left(000^{\prime} 000 \text { PLN) }\right.\end{array}$ \\
\hline Preferential credits & 14867 & 4696 \\
\hline \multirow{8}{*}{$\begin{array}{l}\text { RDP 2014-2020: } \\
\text { - farm modernization } \\
\text { - investment in farms located on Nitrate Vulnerable Zones } \\
\text { - investment in farms located on Natura } 2000 \text { areas } \\
\text { - restoration of agricultural production capability } \\
\text { - start-up aid young farmers } \\
\text { - restructuring of small farms } \\
\text { - TOTAL }\end{array}$} & & \\
\hline & 13526 & 2813.6 \\
\hline & 102 & 4.0 \\
\hline & 0 & 0.0 \\
\hline & 242 & 7.2 \\
\hline & 8863 & 886.3 \\
\hline & 8451 & 507.1 \\
\hline & 31184 & 4218.2 \\
\hline
\end{tabular}

1 in the case of preferential credits, the value of granted credits in nominal terms Source: Annual Reports on Activity of the ARMA (2004-2007). ARMA. Warsaw 2005-2008.

The radical reduction of possibility to use the preferential credits for financing the investment in agriculture caused the immense decrease in the number and the value of subsidised credits granted by banks during 2014-2017 (Table 4). But what is remarkable, the value of the credits is higher than the value of achieved agreements within the enlisted in the Table 4 measures (operations).

The comparative statistics of the interest of agricultural agents in the preferential investment credits and participation of farmers in investment measures offered under SOP and Rural Development Programmes in 2004-2017 is shown in Table 5. Data concern only indicated measures.

\title{
Number and value of investment subsidised investment credits versus number and value of subsidised investment projects in agriculture under RDP in 2004-2017
}

\begin{tabular}{|l|c|c|}
\hline \multicolumn{1}{|c|}{ Specification } & Number & Value $^{\mathbf{1}}$ (thousand PLN) \\
\hline Preferential credits & 177397 & 29500.4 \\
\hline SOP, RDP 2004-2006,2007-2013, 2014-2020 & 298466 & 23061 \\
\hline
\end{tabular}

1 in the case of preferential credits the value of granted credits in nominal terms

Source: Annual Reports on Activity of the ARMA (2004-2007). ARMA. Warsaw 2005-2008.

The data show that although the total number of preferential investment credits is much lower in comparison with number of the subsidised projects within the EU measures, the total value of the granted credits is higher noticeably. It illustrates the importance of the state aid for investment in agriculture during examined period. However, as data for current financial perspective suggest, the role of the preferential credits falls gradually mainly due to reduction of the credit lines.

\section{Conclusions}

1) In the examined years 2004-2017, the Polish farmers were given support from the state and within the CAP. The tools, terms and scope of the support from these two sources were different.

2) The state credit aid system in years of Poland's membership in the EU has been nearly similar like credit support before 2004, however, since 2015 the scope of the credit aid has been reduced noticeably.

3) The comparison of the number and value of the aid given within state credit aid system and RDP during three financial perspectives indicates the very important relative role of preferential credits in financing the modernisation of the Polish agriculture. 
4) Nearly one quarter of market oriented agricultural holdings used preferential credits in years 2004-2017 while, the small and semi subsistence farms were important group of beneficiaries of RDP.

5) Although the substantial difference between the nature of the state and EU aids (repayable credits and subsidised expenditures), they complemented each other.

6) The decrease in the number of preferential credit lines and fall in the number of granted credits suggest that the role of the preferential credits in modernisation and restructuring of the agriculture will fall unavoidably.

\section{Bibliography}

1. ARMA. (1995-2018). Annual Reports on Activity of the ARMA. (1994-2001). Warsaw.

2. Brodeur, C., Clerson, F. (2015). Is Government Intervention in Agriculture Still Relevant in the $21^{\text {st }}$ Century? Final Report. Groupe AGECO, Quebec, p, 54.

3. Central Statistical Office. (1991). Statistical Yearbook 1991. Warsaw, p.596.

4. Danilowska, A. (2004). Agricultural Credit Market in Poland - Experiences in Market Economy, Studies on the Agricultural and Food Sector in Central and Eastern Europe. Volume 25. "The Role of Agriculture in the Central and Eastern European Rural Development: Engine of Change or Social Buffer?. IAMO. Halle, pp. 101-118.

5. Danilowska, A. (2015). Provision of Public Goods by Agriculture in Poland. Economic Science for Rural Development, Volume 37, pp. 142-151.

6. European Commission. (2006). Community guidelines for State aid in the agriculture and forestry sector 2007 to 2013. Retrieved: https://publications.europa.eu/en/publication-detail/-/publication/e3a5a48b-ee544847-bad0-4ef947599d85/language-en. Access: 12.01.2019.

7. European Commission. (2013). Commission Regulation (EU) No 1408/2013 of 18 December 2013 on the Application of Articles 107 and 108 of the Treaty on the Functioning of the European Union to de minimis Aid in the Agriculture Sector. Retrieved: https://publications.europa.eu/en/publication-detail//publication/a2525e65-6c74-11e3-9afb-01aa75ed71a1/language-en. Access: 12.01.2019.

8. European Commission. (2014). Commission Regulation (EU) No 702/2014 of 25 June 2014 declaring certain categories of aid in the agricultural and forestry sectors and in rural areas compatible with the internal market in application of Articles 107 and 108 of the Treaty on the Functioning of the European Union. Retrieved: https://publications.europa.eu/en/publication-detail/-/publication/c011ecad-0102-11e4-831f01aa75ed71a1/language-en. Access: 12.01.2019.

9. Eurostat. (2019). Agricultural Census in Poland. Retrieved: https://ec.europa.eu/eurostat/statisticsexplained/index.php?title=Archive:Agricultural_census_in_Poland. Access: 8.01.2019.

10.FADN. (2004). The Results Obtained by Individual Agricultural Holdings Conducting Accountancy in the Year 2003, Warsaw, p. 48. Retrieved: http://fadn.pl/wp-content/uploads/2013/06/wyniki_2003_ang_011.pdf. Access: 5.01 .2019$.

11. Hagedorn, K. (2008). Particular Requirements for Institutional Analysis in Nature-Related Sectors, European Review of Agricultural Economics, Volume 35 (3), pp. 357-384.

12. Hvid, A. (2014). Agricultural Rent-seeking in Developing Countries: an Empirical Investigation, Journal Applied Economics Letters, Volume 21, Issue 14, pp. 951-954.

13. Jelic, M.A., Durovic, J.M., Radojcics, M., Anicic, J. (2014). Reasons for Government Intervention in Agriculture, Annals of the University of Oradea Fascicle of Management and Technological Engineering, Issue 3, pp.174-179.

14. Jongeneel, R.A., Ge, L. (2010). Farmers' Behavior and the Provision of Public Goods: Towards an Analytical Framework. Wageningen, Statutory Research Tasks Unit for Nature \& the Environment (WOT Natuur \& Milieu), WOtwerkdocument 203, p. 64.

15. Katto-Andrighetto, J., Bowen, D., Varini, F., D'Amico, S., Kirchner, C. (2017). Guidelines for Public Support to Organic Agriculture, IFOAM-Organics International. Retrieved: https://www.ifoam.bio/sites/default/files/policy_toolkit_main_report.pdf. Access: 10.01.2019.

16. Marsh, J. (1992). Agricultural Policy Reform and Public Goods. OCDE/GD(92)56, Paris. Retrieved: http://www.oecd.org/officialdocuments/publicdisplaydocumentpdf/?cote=OCDE/GD(92)56\&docLanguage $=E$ n. Access: 3.01.2019.

17. Moor, T.G. (1987). Farm Policy: Justifications, Failures and the Need for Reform, Federal Reserve Bank of St. Louis. Retrieved: https://files.stlouisfed.org/files/htdocs/publications/review/87/10/Farm_Oct1987.pdf. Access: 5.01 .2019$.

18. Nedergaard, p. (2006). Market Failures and Government Failures: A Theoretical Model of the Common Agricultural Policy. Public Choice, Volume 127, Issue 3-4, pp. 85-405.

19. Paapi, F.U., Henning, C. (1999). Organization of Influence on the EC's Common Agricultural Policy: A Network Approach. European Journal of Political Research, Volume 36, pp. 257-281.

20. Poczta-Wajda, A. (2016). Interest Groups and Rent Seeking in Agriculture - a Theoretical Approach, [in:] B. Czyzewski (Ed.), Political Rents of European Farmers in the Sustainable Development Paradigm International, National and Regional Perspective, PWN, Warsaw, pp.48-58. 
Proceedings of the 2019 International Conference "ECONOMIC SCIENCE FOR RURAL DEVELOPMENT" No 52

Jelgava, LLU ESAF, 9-10 May 2019, pp. 222-230

DOI: $10.22616 / E S R D .2019 .125$

21. Romstad, E. (2002). Policies for Promoting Public Goods in Agriculture. Xth EAAE Congress. Zaragoza 28-31 August 2002. Retrieved: http://agecon.lib.umn.edu. Access:10.01.2019.

22. The European Network for Rural Development. (2015). 2014-2020 Rural Development Programme: Key Facts \& Figures POLAND. Retrieved:

https://enrd.ec.europa.eu/sites/enrd/files/pl_rdp_qnt_summary_v1_2.pdf. Access:15.01.2019.

23. Vanni, F. (2014). Agricultural Public Goods. The Role of Collective Action. Springer, p 150.

24.Zawojska, A. (2011). Rent-Seeking and Lobbying in the EU's Common Agricultural Policy, Roczniki Nauk Rolniczych (Annals of Agricultural Sciences ), Volume 98, Issue 3, pp. 63-72. 